\title{
Twelve Chinese Zoosigns of Zodiak: Tradition and Modernity
}

\author{
Vladimir N. Denisenko $₫$, Zheng Yu Xu \\ Peoples' Friendship University of Russia (RUDN university), \\ 6, Miklukho-Maklaya str., Moscow, Russian Federation, 117198
}

$\varangle$ denisenko-vn@rudn.ru

\begin{abstract}
The work is devoted to the origins and peculiarities of zodiac signs in the ancient Chinese tradition. The study is carried out within the frames of linguocultural approach towards interpreting animalistic metaphors, namely, the zoonyms of the twelve zodiac signs which in China, are used to characterize people concerning their date of birth and are passed on from generation to generation. Chinese zodiacs are based on the astronomic theory of constellations and human worship (idolatry) of totems. It focuses on the comparison of zoonym metaphors reflected as Chinese zodiac signs both in the Chinese and Russian languages proceeding from the theory of metaphor in modern cognitive aspect to detect similarities and differences, and as well, the study of cultural roots of zoonym metaphors revealed in the Chinese zodiac signs. The object of the study concerns zoonyms of zodiac signs possessing the relevant meaning in the Chinese zoological lexis. The work elaborates the definition of the notion "zodiac", describes the processes of the genesis, formation and development of the Zodiac culture and its specific cultural relevance; according to the analysis undertaken, the means to differentiate twelve animals of the Chinese Zodiac, and those of Chinese fairy tales, on the one hand, and, on the other hand, in Russian - animals were discussed and verified as to I.A. Krylov's fables. The conclusion states that metaphors are determined by the language itself, and linguocultures of various nations are reflected in specific metaphors and other peculiarities.
\end{abstract}

Key words: metaphor, zoonymic metaphor, origins, Chinese zodiac, zodiac culture, contrast

\section{Article history:}

Received: 01.03.2021

Accepted: 15.09.2021

\section{For citation:}

Denisenko, V.N. \& Xu, Zheng Yu. (2021). Twelve Chinese Zoosigns of Zodiak: Tradition and Modernity. RUDN Journal of Language Studies, Semiotics and Semantics, 12(4), 1299-1313. doi: 10.22363/2313-2299-2021-12-4-1299-1313

(C) Denisenko V.N., Xu Zhenyu, 2021

This work is licensed under a Creative Commons Attribution 4.0 International License https://creativecommons.org/licenses/by/4.0/ 


\title{
Двенадцать китайских знаков зодиака: традиция и современность
}

\author{
В.Н. Денисенко $₫$, Чжэнюй Сюй \\ Российский университет дружбы народов, \\ 117198, Российская Федерация, Москва, ул. Миклухо-Маклая, 6 \\ $\square$ denisenko-vn@rudn.ru
}

\begin{abstract}
Аннотация. Работа посвящена проблеме происхождения и особенностей знаков зодиака в древней китайской традиции. Данное исследование выполнено в рамках лингвокультурного подхода к изучению метафор животных, связанных с двенадцатью знаками зодиака, которые в Китае используются для характеристики людей в зависимости от даты рождения и передаются из поколения в поколение. Китайский зодиак также основан на астрономической теории созвездия и поклонении людей перед тотемами. Цель исследования - сравнить метафоры животных из китайских знаков зодиака в китайском и русском языках на основе теории исследования метафоры в современном когнитивном аспекте, выявить сходства и различия, а также культурные корни метафор животных в китайских знаках зодиака. В качестве объекта исследования выбраны животные знаков зодиака, имеющие репрезентативное значение в китайской зоолексике. В работе дано определение понятия «зодиак», описаны процессы зарождения, становления и развития зодиакальной культуры и ее специфическое культурное значение, проанализировано, чем двенадцать животных из китайского зодиака отличаются от русских животных на материалах басен И.А. Крылова и китайских народных сказок. Делается вывод о том, что между языком и метафорами очень тесная связь: лингвокультура разных народов отражается в специфических метафорах и других особенностях.
\end{abstract}

Ключевые слова: метафора, метафора животных, происхождение, китайский зодиак, культура зодиака, контраст

\section{История статьи:}

Дата поступления: 01.03.2021

Дата приема в печать: 15.09.2021

\section{Для цитирования:}

Denisenko V.N., Хu Zhenyu. Twelve Chinese Zosigns of Zodiak: Tradition and Modernity // Becтник Российского университета дружбы народов. Серия: Теория языка. Семиотика. Семантика. 2021. Т. 12. № 4. С. 1299-1313. doi: 10.22363/2313-2299-2021-12-4-1299-1313

\section{Introduction: Peculiarities of the Chinese Zodiac}

The relevance of the study's issue is determined by the fact that the description of the signs of the Chinese Zodiac 生肖 (shengxiao) is also known as "The Calendar of Zodiac Signs marking the Man's Year of Birth" and includes symbolic animals: a rat, an ox, a tiger, a rabbit, a dragon, a snake, a horse, a goat (sheep), a monkey, a rooster (hen), a dog and a pig [1]. The word-hieroglyph «生» (Sheng) means 'the year of birth', and «肖» (Xiao) denotes 'resemblance and similarity' which makes 
生肖 (Shengxiao) meaning 'zodiac sign of the year of birth'. It also means that the birth of a man is connected with a certain animal symbol.

The Chinese Zodiac develops on the basis of worshiping animals and totems of the ancestors, and long time ago it has become conventional and universal for the Chinese people. Each zodiac animal has gradually acquired its own unique metaphorical meaning.

Twelve zodiac signs are visual representatives of the twelve Earthly Branches, namely: 子 [shŭ] 'a rat'; 丑 [niú] 'an ox'; 寅 [hŭ] 'a tiger'; 卯 [tú] 'a rabbit'; 辰 [long] 'a dragon'; 巳 [shé] 'a snake’; 午 [mă] 'a horse'; 未 [yang] 'a goat'; 申 [hóu] 'a monkey’; 西 [jī] ‘a rooster'; 戌 [gŏu] 'a dog'; 亥 [zhū] 'a pig'. In course of history, national beliefs gradually formed a conception of mutual emanation and mutual inhibition, which is revealed in human life, in marital relations, a yearly well-being, etc. Each animal of the Chinese Zodiac has got an opulent history, and many legends are told of it. It's formed the systemic base to interpret the notions which has become the philosophy of images in the folk culture, e.g., zodiac signs for marriage, prayers and devotions and dates of birth. Nowadays more and more people consider a Chinese zodiac sign to be an amulet of the coming new year and the symbol of cultural events and entertainments.

Zodiac signs have been quite close to everyday and social life of people since long time ago. And those twelve animals one can tentatively divide into three categories.

The first category involves six domestic animals which were tamed by a man long time ago. Those are: an ox, a goat, a horse, a pig, a dog and a rooster as the people have domesticated them for the household and other purposes.

The second category concerns five wild animals as a tiger, a rabbit, a monkey, a rat and a snake. Among those, there are some who are in fear and tremble in front of people, and the other ones, on the contrary, intermeddle in human lives, e.g., tigers and snakes. People used to hate rats, as well. The greater part of people like rabbits and monkeys, though these animals are not domesticated yet, they are closely connected with people in their everyday life, so they were included in the list of zodiac signs.

The third category makes a traditional amulet of the Chinese nation. A dragon is the only imaginary, mythical animal of the Zodiac and the result of the totem human worship in the ancient society. A dragon evokes a particular feeling among the Chinese. In the Chinese national consciousness a dragon is a kind of God who can cause the wind and rain, who can levitate in the sky, and banish the fog and mist. It has got the highest status. Although a dragon is a sort of a spiritual fabulous creature, it makes the symbol of the Chinese nation. A dragon incarnates wealth and is the most symbolic merciful animal, so the dragon's presence in the Zodiac is typical and natural.

The Zodiac culture proposes the relations between people, nature and society. It contains deep ideas, conceptions and is closely connected with the real world, to 
the full extent, reflecting customs, models of thinking, values, ethics and aesthetical tastes of different types and places.

Zodiac represents an ancient symbol of the folk culture. There are a great many of poems, couplets, pictures, calligraphic patterns and folk trades depicting the zodiac sign images. Both in China and in many countries worldwide, as well, there are published postal stamps devoted to Chinese zodiacs, and the Chinese New Year is celebrated [1].

\section{Reasons and motives of the Chinese Zodiac culture genesis and linguocultural significance of the Chinese zodiacs}

The genesis and origins of any culture have their own imminent historic reasons, and particularly but not exclusively, it concerns the Zodiac culture. Already at the times of the Han dynasty, the people of China started to use the Calendar of the Heavenly Stems and Earthly Branches. The complete Calendar of the Heavenly Stems and Earthly Branches was found even in the inscriptions on the oracle bones. Ye Shu-Xiang was the first one to draw the conclusion that "to write down and fix the span of twelve years, the notion of the twelve Earthly Branches is abstract, complicated and not comfortable to remember, so the twelve zodiac signs are used to fix the year span" [2]. Actually, there exists a certain link between the zodiac culture and astronomy; there also exists a certain link between the origins of zodiac animals and the Jupiter cycle. The influence of the Totem culture on the Zodiac culture is also quite evident.

The primary significance of the Zodiac culture might possibly be revealed in the writing down of a year, month and day, so that they might be connected with "the Heavenly Stems and Earthly Branches" to form a new type of dating. With the evolution of "Yin and Yang" theory, the appearance of five elements and a number of fatalistic approaches, the Zodiac culture gradually started to be connected with the year of birth and human destiny thus becoming widespread. In “王红旗. 神妙 的生肖文化与游戏. 北京: 三联书店 (“A Wonderful Culture and the Chinese Zodiac Games') [3], Wang Hong-Ji wrote that the genesis of the Chinese Zodiac culture has got its own imminent cultural significance: as soon as on the Earth there exists a twelve-year cycle of biological development, each one of those twelve years suits the growth of a certain animal. If the people born in a year of a certain animal can model themselves on this animal, it's useful for their development, too. Which is why, the zodiac sign of a man is denoted by a definite animal which becomes his symbol. This year is called by the name of the animal whose imitation would help a man develop and grow. Wang Hong-Ji assumes that the essence of the Zodiac culture lies in connecting the time of birth of a man with a definite animal and to a certain extent, in foretelling the behavior of some people.

Chang Hao wrote in the work "Twelve Chinese Zodiac Signs": "According to the astronomic calendar, in fact, any Chinese Zodiac visually denotes the time of the Heavenly Stems and Earthly Branches [4]. It confirms that the relations between Chinese Zodiacs and Earthly Branches are inseparable. 


\section{The Origins of Zodiacs}

The Chinese theory of the origins of zodiacs could be explained by the following assumptions.

\section{Chinese zodiacs descended from worshiping totems}

Main scholars studying Chinese zodiacs are Ha Sing Lang. Dong Zi Jian, Lu Yao Hang. So, Dong Zi Jian assumes that the ancient surname and the zodiacs have a common origin. According to the text studies by $\mathrm{Gu}$ Yanwu (born Gu Jiang), in the time of "Spring and Autumn", there existed only 22 Chinese surnames. Proceeding from this historic datum, Dong Xi Jian believes that the most ancient surnames are just twelve family names which originated from the names of 12 animals - the totems of the ancient society. In "The Study of Ancient Family Names and the Chinese Zodiacs as Totems", he wrote that twelve animals came into being from the totems. Ha Sing Lang in his study "Totems Culture and the Origins of Human Cultures" refers to the articles by Dong Zi Jian "Ancient Family Names and Zodiac Totems" (1946) and "The Calendar of "Twelve Animals", which emerged from "The Legends of Totem Worships of the Primitive People" collected by Lu Yao Hang (1979). Comparing the ides of both scholars, Ha Sing Lang made a conclusion that "from different points of view, these articles explain that all the twelve animals and zodiac signs of ancient Hang people and ethnic minorities arouse from totems". Ha Sing Lang also approves the assumption that the Zodiac culture originated from the totem worship, which is partially reasonable" [5].

\section{Chinese zodiacs were stimulated by animal worship}

Mao Zemin and Fang Zhou make a remark in "The Great Opinion of the Chinese Zodiac Words": "The correlation between the twelve Earthly Branches and animals appeared due to the worshiping animals in ancient times" [8].

As to the interconnection between the twelve branches of animals and the year of a man's birth, in the times of the "Southern and Northern Dynasties", there were references to such zodiac signs of people as "Dun Hung was born in the year of a pig", "Zhui Hua Zing was born in the year of a horse" [Southern tzi-five elements; the author is Ban Gu also called Mengjian (AD 32-92), a Chinese historian and poet, the creator of 'dynasty history' genre.

In his study "Twelve Zodiac Signs and Life" (2005), Zhuhou stated that "twelve branches were skillfully used in Yin and Shang dynasties, and zodiac signs appeared only in the times of "Spring and Autumn". Zodiac signs were created later than the twelve Earthly Branches, and they were attached to the twelve branches. Twelve kinds of animals were chosen. As symbols of the twelve Earthly Branches, the Zodiac emerged from the psychology of worshiping animals by ancient people" [7]. But his assumption is not approved academically. Modern studies don't let 
accept the definite conclusion concerning the correlation between zodiacs and the Heavenly Stems and Earthly Branches.

The ancestors of the primitive society often used like a totem some definite animal, an inanimate object or natural phenomenon as the protector or symbol of the clan. Mixed pictures of people and animals in "Shang Hai Zin" (one of the three great books of ancient China) are totems of gods of ancient times except for a dragon, which is an illusion, and one can see zodiac signs every day. They can also be divided into two categories: six domestic animals (a horse, an ox, a goat, a rooster, a dog, a pig) and six wild animals which were feared by our ancestors (a rat, a tiger, a rabbit, a dragon, a snake, a monkey) [8]. Those animals were worshiped as the name of the clan.

Ethnologist $\mathrm{Lu}$ Yao Hang proceeded from the assumption of totem relics of the nation and changed the idea of the origin of "The Twelve Animals Calendar". In "Mao Dao Y" and "Guy Shi Y" - the twelve animals calendars - there are listed together a man and twelve animals to describe the chronology of the tome between the years of 1922-2012. Until now, people use twelve animals to register the date, and to give the names of streets, e.g., Tiger street or Rabbit street, as well. In "Historic Chronicles of Five Emperors" (known as 'Shiji'), Sima Qian, a writer and historian of the Han Dynasty, wrote that the Yellow Emperor (206 BC-24 AD) "tamed a brown bear, panther and tiger and with them, he fought against the Yan Emperor in the Ban Xuan jungle" [4]. Those three animals could be referred to as totems of different ethnos. Thus the Chinese Zodiac originated from the worship of totems of the primitive society and became a solid theory.

The goal of the totem classification is the division of ethnic groups. Let's discuss the totem of a bird, for example. The bird Phoenix is connected with the Shijiahe culture: the totem "Bird" is connected with the Liangzhu culture, and the totem "Eagle" belongs to the Longshang and Liangjitang cultures. So different systems could be mentioned. Those few cultural systems are mainly parallel, but their basic cultural structure has got similarities which demonstrate the obvious proximity of cultural ties. Both regional character and similarities in the so-called Jade culture are the results of irregular and unbalanced development, convergence and emanation of the early Chinese cultural variety which adequately correlates with the general evaluation of the ancient Chinese civilization in the cultural archeological studies. The "Jade Bird" and "Jade Phoenix" were widely spread in the times of Shang and Zhou. The piece of handiwork as a jade handle, or "Phoenix pattern" is a typical decoration for the Western Zhou dynasty. The Shang dynasty had also got "Phoenix pattern" which inherited the tradition of the Shijiahe culture and differed from the Western Zhou Phoenix. The birds of the Shang dynasty actually differ from the birds of the Liangzhu culture; the Zhou dynasty Phoenix differs from that one of the Shijiahe culture. But all those images could have naturally reproduce distinct general features of the configuration which means they rest upon the cultural continuity. 


\section{The Chinese Zodiac resulted from the astronomic theory of constellations}

As to the origin of the Chinese Zodiac, modern academic studies principally focus on the two periods of the prehistoric epoch and the Zhou dynasty. It's worth precising here that the Zodiac isn't formed at a single stage, it doesn't make a single step, as its formation and development is a long and flexuous process.

Zhang Hao put forward the following conclusion in his work "The Twelve Zodiac Signs": "The Shang dynasty has already used "Stems and Branches" symbols, as well as a few zodiac symbols of animals. By the time of the Spring, Autumn and Fighting Kingdoms, the names of the Zodiac were mainly formed, and they were finalized in the times of the Han dynasty, since when the Zodiac became popular" [10]. Sill, other points of view seem more rational.

Ancient people distinguished stars and constellations, arranged near to the ecliptic and the Equator, into 28 constellations, or "houses". Accordingly, twentyeight "houses" represent the animal varieties. In ancient times, a week and the Heaven were divided into 12 equal parts, represented with 12 Earthly Branches, and 12 governors belonged to a certain zodiac sign; between a zodiac sign and 28 stars there was established the adequate correlation [7]. A scholar of the Min dynasty Wan Hua believed that 28 kinds of animals belonged to the 28 constellations, and they were united by "the seven looks" thus forming the image of "the Earthly Bat female species, virtual Solar Rats, dangerous Moon Swallows" [7]. Lìng Chen Qíng of the Quin dynasty believed in "Sun Xia Guan Zou Yan", which means that 28 animals-residents existed, e.g., "the first twelve houses doubled" (28 kinds of archeological animals according to the Chinese Zodiac). However, the concomitant association is inevitable, and the record of the 28 stars with corresponding animals appeared later then the twelve zodiacs.

\section{The Chinese Zodiac originated due to the Jupiter Theory}

Number 12 was obtained on the basis of ancient observations of the heaven, and it was firstly used in the Chinese calendar of the $613 \mathrm{BC}$. Ancient people discovered that the Sun and the Moon rotate in ecliptic way during a week and meet each other exactly 12 times a year. The ancestors of the Chinese people established the period of 12 years as the first epoch, because the Jupiter could be seen just one day out of all the 12 years of the heavenly phenomenon. Zoon-ho wrote in "The Twenty Signs of Zodiac and Life": "Ancient astronomy divides the Heavens 12 times. The stars move once a year, and one day of the twelve years is called the first period. The first period equals twelve years" [10]. In China, the twelfth day of the Sun and the Moon means they meet in the East, which actually is the twelfth hour. In spring, summer, autumn and winter a month is determined by the Baidu navigation (the Chinese satellite navigation system), and there exist twelve "houses". This helps draw the conclusion that ancient people viewed the astronomy and calendar system under the umber "twelve". 
"Twelve is the great Heaven number" — this is the result of the observations of ancient people. There is no discord on the issue. The Heaven itself also reflects the birth of the Chinese Zodiac and the harmony of the stars, establishes the connections of calendars.

The Jupiter moves just one day and appears once in 12 years, and the yearly sequence of the Branches could be determined according to the Jupiter's position. Thus, the source of "The Collection of the Lost Books in the house of Yu Han Mountain" tells us that every 12 years one can observe: "Rang devastated at the age of three, Kang at the age of three, and the draught of the three years running, and hunger of each year" [11].

The rise and fall of the plants and the animal life environment develop in cycles. Life habitat of the herbivores (rats, cows, horses, goats) and fleshy-eaters and omnivores greatly vary from year to year. If people born in different years can assume the examples of wild animals in that very year, the formation of zodiac animals is taking place to agree that the rise and fall of animals is connected with the Jupiter year, and the Zodiac and 12 heavenly years are united.

\section{Comparison of the metaphors of zoonyms of the Chinese and Russian Zodiacs}

A pig is the most ancient domestic animal, raised by people; it gives to them a great many of meat. In ancient China, pigs were considered to be the symbol of wealth, due to the limited production and low economic development. Pigs lived in the man's house. The skills to breed pigs was the symbol of family and property. The Chinese hieroglyph 家 'a house' means a pig 《豕》 under the roof 《r». However, with the economic and cultural development, with changes in human mentality the image of a pig has gradually changed. So far as people used to keep pigs in captivity, the pigs eat and drink in a small paddock, the man's impression of pigs has gradually changed as of a lazy, stupid, greedy, ugly animal. And its metaphorical meaning also became pejorative.

In Russian culture, the image of a pig is similar. For example, in I.A. Krylov's fable "The Pig under the Oaktree", the Pig is characterized negatively. The Crow tells the Pig: "If you lay the roots bare, the tree could wither", and the Pig answers: “Though it doesn't exist for a century, I wouldn't pity it. Let just the acorns stay: I'm getting fat on them". ${ }^{1}$ It speaks for the Pig's stupidity and ingratitude.

The Pig in the I.A. Krylov's fable "The Pig is also illiterate and stupid. Without seeing god and new around itself, it can see just bad: "I haven't seen any wealth at all — just dung and litter".

In ancient times the snake was considered the dragon's prototype, so in the Chinese the name of a snake is also a "little dragon". In the Chinese culture snake were treated as spiritual relics, they were worshiped since long ago. In legends and

\footnotetext{
${ }^{1}$ The translation is literally to render the meaning of phrases. - The authors.
} 
myths of the Chinese people, the forerunners of humanities - Fusi and Nuva had human faces but snake's bodies, and their interaction helped to move up to the people. The idea that a snake could become dangerous, was born in the times of the Western Han dynasty. Since then, the number of folk legends about snakes torturing people, has grown; they started to play the role of monsters, and the snake at sight meant misfortune and disaster. Besides, snakes are cold-blooded animals of strange exterior, who creep on their own body; they are aggressive towards people, so they cause even geater disgust and fear among the people. Some snakes are also very venomous, so a snake is called "the head of five venoms". In Chinese, the wordcollocation of "snake's heart" is often used to describe evil and angry people. Thus in Chinese, the metaphoric meaning of a snake mainly symbolizes something vicious, evil and cunning.

In the Russian culture, a snake is also angry and bloodthirsty. In the fable «The Boy and the Snake" by I.A. Krylov, the Boy seized the Snake, and the Snake said: "This time, the God would excuse you, but take care for the future and learn who you may play jokes with", and then it ate the Boy.

According to Charles Darwin's theory, human beings got their origin from primates, and many of their habits are similar to the monkey's ones, so people are much more closer to monkeys than any other animals. The word 猴 (hou) — 'a monkey' is a homonym to the word 猴 (hou), denoting the rank and title in ancient China. Which is why in the traditional Chinese culture the Monkey zodiac symbolizes good luck. Monkeys have got a highly-developed brain, so they are clever, so people think that they are mainly clever, disobedient and sweet. In the narrative “A Dream in Red Mansions” (traditionally 紅樓夢 “Hongloumeng'), one of the four great Chinese masterpieces, the author always uses the theory of body moves, e.g., guessing a riddle, the character Baoyu ran up to the Sky lantern ('kongming') and 'gave instructions right and left with ample criticism, saying, it was no good one, the other one was broken and unhappy like a dismembered monkey". He literally used an expression "towards he-monkey" and "the bowel of he-monkey" (both bearing grammatical masculine gender!) to describe disobedient and mischievous Jia Baoyu (the main character of the narration "A Dream in Red Mansions"). And though monkeys are clever and quick of foot, they are also cunning and restless. In the masterpiece “Journey to the West” (西遊記 1592) by Wú Chengen (1500-1582) the King of Monkeys demonstrated typical monkey features to the full extent and deeply impressed people. But in the Chinese language, the metaphoric significance of monkeys is mostly negative.

In the fable "Monkeys" by I.A. Krylov the Monkey is hypocritical and shortsighted. The monkey catcher was purposely rolling in the net on the grass, and the monkeys mindlessly started to follow his suit — in nets, "somersaulting, rolling, shouting, screaming — terrific fun!" without noticing any danger for themselves. When monkeys had to get out of the nets, "no one could have disentangled, and were taken with man's hands" [13. P. 50]. 
A goat is a passive animal by nature, and for the majority of Chinese it personify lenience and kindness. The word "good" of the first version of 三字经 “Three Character Kanoon' (lit. 'three, a hundred, a thousand'), or "The ABC of the Chinese language" says that "The human origins is "good" and it comes from the word 'goat'. To a certain extent, it also reflects the strife of ancient Chinese governors to make the people passive, obedient and easy to be governed. In Chinese, the expression "obedient little goat" is often used to describe obedience and timidity of people. From time to time, the zoonym 'goat' is used to denote honest and noble people, e.g., the Chinese fable

《神羊盗五谷的传说》 ('The Legend of the God and the Goat Stealing Grain') told that the goat stole grain from the God to save people from hunger, but finally, 玉帝知道这件事之后十分生气, 他命天神将羊拉到人间屠宰 (the Jade Emperor was very angry when he learnt about this and ordered gods to bring goats to the Earth to slaughter them) [11].

In I.A. Krylov's fable "The Wolf and the Lamb", Lamb is naïve and weak. The little Lamb went to the stream to drink water, but "there was the trouble". The Lamb wasn't guilty at all, but the Wolf still dragged the Lamb to the forest saying: "You are guilty because I want to eat".

Just because goats are quite obedient, they used to make an object of intimidation and fear. So the goat-metaphor means weakness, cowardice and obedience.

When one speaks of oxen, the Chinese often think of "hardworking" and “earnestness'. Due to breeding the cattle, the Chinese become closely attached to cattle species, and they render to those such nice qualities as honesty and hardworking [12].

China is a vast agrarian country. In ancient times, agriculture was there was the base and the cornerstone of the economic development. And cattle made the important element of the agriculture. People use to think of cattle as hardworking, selfless, devoted help in hard work. According to the famous legend "The Shepherd and the Weaver", the Cow fully devoted itself to the Shepherd Boy, which to the full extent embodies selfless and hard work. In the fable «牛神被贬的传说》 ('The Legend of Demoting the God-Ox') the Ox is really hardworking. After the demoting, the God-Ox' had truly to help people turn up the soil in the fields ('牛神 只好老老实实帮助人们犁田耕地”) [12].

In the fable "Animal Pest" by I.A. Krylov, the Ox is obedient and sincere. For his honest confession that he "had stolen a clump of hay of the priest's haymow", he was punished: "the Ox was put on fire".

In ancient China a horse was the main driving force as to transport and military activity, which is why it plays an important role in history. Metaphoric significance is multifaceted. Horses might be useful not only for crop farming, but to transport 
people and loads, to wage wars. They move fast, so people consider horses be a symbol of speed and talent.

A tiger is the King of animals, and in ancient China it is denoted by two hieroglyphs — 寅 ('Yin') and 虎 ('tiger'). The word 寅 ('Yin') as an inscription on the oracle bones looks like an arrow, and this image combines both cruelty and virility. If cannibalism of the Bronze Tiger of the Sheng dynasty period reflects the ancient people's fear of tigers, the sign of tiger during the war symbolizes the intention to gain a victory. In battle, "the White Tiger Flag" means 'a brave man', or 'tiger's general' - simultaneously a tiger amulet and a weapon of tiger stripes color [11]. Tiger's forehead is broad and resembles the Chinese hieroglyph 王 ('Wan'), symbolizing strength and courage. Tiger's appearance means powerful, and its character is both brave and cruel, so the image of a tiger has got two absolutely different significances.

In Chinese fables, the Tiger personifies strong, powerful, heroic and decisive people. As in the Chinese fable 狐假虎威 (lit. 'Fox uses the Tiger's Power') the Tiger is powerful, influential and strong: 野兽们见了老虎, 纷纷跑开了('Animals saw the Tiger and ran away').

In Russian fables, tiger's place is occupied by a lion. So in I.A. Krylov's fable "The Lion and the Wolf" the Lion is the King of animals, extremely strong and powerful. When during breakfast a small dog stole some meat from him, the Lion "didn't pay any attention and had no regret", but when the Wolf stretched the paw towards the Lion's dish, the Lion didn't let it off and tore the Wolf to pieces. This is the revelation of the Lion's strong and cruel character.

In ancient China the main use of dogs was to protect the house; their status was not high, and much more attention was paid to dogs' obedience. Moreover, in ancient times only powerful people could breed dogs, so in the traditional Chinese culture dogs are the symbol of obedience and power and are often horrible villain. In modern China dogs are usually fed as domestic animals. As dogs are devoted to people, they are not just those mostly beloved domestic animals, but are also considered to be true partners and good friends. Many people even consider dogs as the family members.

For example, in the fable 义犬救主的故事 ('The Story of the Holy Dog-Life Savior’) the Dog is a devoted and brave animal: “船上的黄狗见商人遇险, 便毫不 犹豫地跳入了河水中, 想要救起商人” (“Having seen that the owner is in danger, without any doubt, the Dog jumped into the river and saved him').

In I.A. Krylov's fable "The Dog, the Man, the Cat and the Falcon" the dog's image is similar to its image in the Chinese culture. So, when "the Bear opened his mouth widely", the Falcon and the Cat ran away, and the Man could have lost his life. Only the devoted Dog stayed and "fought the angry Bear". It speaks in favor of the dog being the loyal and brave character [13. Vol. III. P. 181]. 
In the Chinese mythology a dragon is a magic animal that could fly in the rain, and in the floating clouds, and in the thick fog. In the traditional Chinese culture dragon is always the symbol of well-being. Together with Phoenix, Unicorn and Turtle, Dragon is known as one of the four great animals of China. Dragons were invented by people proceeding from various animals' graphics, but actually they don't exist in reality. However it doesn't influence on the human admiration and worshiping them. In the traditional Chinese culture dragon is the symbol of Imperial power.

The Rooster (or Hen) is the only bird of the Chinese Zodiac. Besides the fact that ii represents the immediate source of food for a man, a hen lays eggs, and rooster is an alarm clock in the morning, so the bird is closely connected with people.

The Rat (or Mouse) occupies the first place in the Chinese list of twenty Chinese zodiacs. The Rat steals food, which is contained in the following Chinese saying: "A hamster has food in plenty". It proves the house is rich, and rats in the house symbolize wealth.

Because of their humble appearance, a tiny body, the know-how to hide and escape, in human perception, rats (mice) are at most thievish and cunning, and their ability to reproduce themselves is highly strong, people used to repugn these animal creatures. In China, rats (mice) are thought to be infestant along with cockroaches, butterflies, mosquitos and flies. Taking into consideration rats' (mice's) appearance, their life patterns and habits and relations with people, In the Chinese language the greater part of words and idioms, referring to rats (mice), contain pejorative meaning, and the metaphor meaning could also be pejorative.

See the fable «玉皇大帝选生肖》 ('The Jade Emperor Chooses the Zodiac'): among zodiacs, the Rat took the first place thanks to the Ox. So one can see that the Rat is cunning and wild.

In the Russian Literature the Rat (Mouse) is an honorable and honest animal. As in the fable "The Lion and the Mouse" by I.A. Krylov, one can read: "The Mouse asked the Lion to make suit to her" as if "at times to be of service to him" [13].

The Rabbit character has got a longtime history in the traditional Chinese culture. When Rabbits are the point of issue, the Chinese used to think of 玉免 ('Yutu') or Jade Rabbit, who accompanied 嫦娥, ('Chang'e') in the Guanghan (广 汉) Palace. Acciording to the folklore sources, the Emperor saw that Chang'e lived alone in the cold and empty Guanghan Palace, so he let Yutu, the Jade Rabbit to reduce medicine to powder under the laurel tree in the Guanghan Palace, and accompany Chang'e. In ancient China the Rabbit was also called 'the Moon'. Besides denoting the Moon, in Chinese, rabbits often symbolize prettiness, gentleness and smartness. Lively and pretty children are often associated with rabbits. In the Chinese language there are many metaphoric expressions connected with rabbits, e.g., the fable «玉免的传说》 ('The Legend of the Rabbit') reads: «我 家里也没有什么吃的能分给你们, 所以你们就把我吃掉吧》 ('I have nothing to 
eat at my home, so you may eat me'). So the Rabbit's kindness and generosity is demonstrated. And in the I.A. Krylov's fable the Rabbit is cunning and boastful [13].

\section{Conclusion}

Finally, due to its specific role in the traditional Chinese culture, the Zodiac culture has become an important integral part of the Chinese tradition attracting much attention.

Proceeding from studying of a great number of historic and literary materials, we came to the conclusion that the development of the Zodiac culture was a really very longtime process, starting from the period of its genesis (until the Zhou dynasty), the period of development and changes (periods of Zhou and Qing dynasties), the period of maturity (the times of the Southern and Northern dynasties of Wai and Qing). At all those stages the Zodiac culture was developing and progressing from the start towards gradual formation, from uncertainty to gradual definiteness, from a single meaning to complexity. At present, this process is no longer a secret or riddle. Moreover, one may conclude, that in course of its formation the Zodiac culture experienced the influence of many factors, including everyday life of ancient people, their worshiping totems, their relations with animals, astronomy, calendar, production and so on. Thus, the process didn't depend on any single factor, the background of its formation was extremely complex. Still, finally, the Zodiac culture was formed and shaped, and we inherited it.

\section{References}

1. Encyclopedia of China (2009). Beijing: Chinese publishing House "Encyclopedia". pp. 20-162. (In Chinese).

2. E, Shuxiang (1998). The Zodiac Culture and its origins. In: Search of the Roots. Beijing. (In Chinese).

3. Wang, Hong-Qi (1992). Remarkable Culture and the Chinese Zodiac Games. Beijing: Sangliang. (In Chinese).

4. Zhang, Hao, Yao, Wei-Jun \& Ju, Hangqian. (2001). The Chinese Zodiac. In: Education of Hubei Province. Wuhan. (In Chinese).

5. He, Xing-Liang (1985). Totemic Culture and The Origins of Human Cultures. Beijing: Chungo Shehui Kesue. (In Chinese).

6. The Beautiful Pictures of the Chinese Zodiac Signs and Words (1990), Mu Tziming \& Fan Zhou (Eds.). Beijing: "Blue Sky" Publishing House. pp. 3-9. (In Chinese).

7. Zhon, Hoe (2005). Twelve Signs of the Zodiac and Life. In: Chinese Business Press. pp. 1-15. (In Chinese).

8. Li, Shijia (2005). The Mysterious culture, Numbers and Zodiac Signs. Hainan: Hainan University Press. (In Chinese).

9. Lu, Yaohang (1986). The October Calendar of the Civilized China. Yunnan: The Yunnan Peoples' Publishing House. (In Chinese).

10. U, Yujchen (2004). The Culture of the Chinese Zodiac. Tianjin: The Tianjin Peoples' Publishing House. pp.19-25. (In Chinese).

11. Series: "The Chinese Zodiac Culture" (2010). Beijing: Foreign Languages Press. pp. 4-30. (In Chinese). 
12. Li, Tziming (2008). The Ox as a Zodiac Sign. Beijing: "Slon” Publishing House. pp. 35—40. (In Chinese).

13. Krylov, I.A. (1945). Complete Works. Vols. I-III. Moscow: Goslitizdat Publishing House. (In Russ.).

\section{Библиографический список}

1. 中国大百科全书编委会. 中国大百科全书: 中国大百科全书出版社, 2009: 20-162. [Энциклопедия Китая. Китайское издательство «Энциклопедия», 2009. С. 20-162].

2. 叶舒宪. 生肖文化及其起源. 寻根. 1998. [Е Шусянь. Зодиакальная культура и ее происхождение. Поиск корней. Пекин, 1998].

3. 王红旗. 神妙的生肖文化与游戏. 北京: 三联书店, 1992. [Ван Хунци. Замечательная культура и игры китайского зодиака. Пекин: Санлиан, 1992].

4. 张皓,姚伟钧, 余和祥. 十二生肖. 武汉: 湖北教育出版社, 2001. [Чжан Хао. Яо Вэйцзюнь, Ю Хэсян. Китайский Зодиак. Ухань: Пресса для образования провинции Хубэй, 2001].

5. 何兴良。图腾文化与人类文化的起源 1992. [Хэ Синлян. Тотемная культура и происхождение человеческих культур. Пекин, 1992. С. 329-333].

6. 穆子敏,方舟. 生肖珍闻词语大观. 蓝天出版社. 1990: 3-9. [Му Цзыминь и Фан Чжоу. Великолепный вид китайских знаков зодиака и слов / Под ред. Му Цзыминь и Фан Чжоу. Пекин: Издательство «Голубое небо», 1990. С. 3-9].

7. 仲候. 十二属相与人生. 中国商业出版社. 2005: 1-15. [Чжунхоу. Двенадцать знаков зодиака и жизнь // Китайская деловая пресса. 2005. С. 1-15].

8. 李时佳. 神秘文化数生肖: 河南大学出版社, 2005: 11. [Ли Шицзя. Таинственная культура, числа и знаки зодиака. Хэнань: издательство Хэнаньского университета, 2005].

9. 刘尧汉. 文明中国的彞族十月历: 云南人民出版社 1986. [Лю Яохань. Октябрьский календарь цивилизованного Китая. Юньнан: Народное издательство Юньнан, 1986].

10. 吴裕成. 中国生肖文化: 天津人民出版社, 2004: 19-25 页 [У Юйчэн. Культура китайского зодиака. Тяньцзинь: Народное издательство Тяньцзинь, 2004. С. 19-25].

11. 丛书编委会. 中国生肖文化: 外文出版社, 2010: 4-30. [Серия «Культура китайского зодиака». Пекин: Пресса на иностранных языках. 2010. С. 4-30.]

12. 李子鸣编著. 十二生肖 牛: 大象出版社, 2008: 35-40. [Ли Цзыминь. Знак Зодиака Бык. Пекин: издательство «Слон», 2008. С. 35-40].

13. Крылов И.А. Полное собрание сочинений в 3 т. М.: Гослитиздат, 1945.

\section{Сведения об авторах:}

Денисенко Владимир Никифорович, доктор филологических наук, профессор, зав. кафедрой общего и русского языкознания, филологический факультет ФГАОУ ВО «Российский университет дружбы народов»; сфера научных интересов: теория языка, лингвистическая семантика, прагматика и семиотика, сопоставительные исследования языков; email: denisenkovn@rudn.ru Scopus Author ID: 57193133860; ResearcherID: A-6522-2017; ORCID: 0000-00016021-4068.

Сюй Чжэнюй, аспирант кафедры общего и русского языкознания, филологический факультет ФГАОУ ВО «Российский университет дружбы народов»; сфера научных интересов: лингвистическая семантика и прагматика, теория текста, стилистика языка и речи; email: 1042198008@rudn.ru 


\section{Information about the authors:}

Vladimir N. Denisenko, Prof. Dr.Sc. (Philology), Professor, Professor-Consultant of the General and Russian Linguistics Department, Philological Faculty, Peoples' Friendship University of Russia - RUDN University. Research interests: theory of language, linguistic semantics, pragmatics and semiotics, comparative linguistic studies; email: denisenko-vn@rudn.ru Scopus Author ID: 57193133860; ResearcherID: A-6522-2017; ORCID: 0000-0001-6021-4068.

$X u$ Zheng $Y u, \mathrm{PhD}$ student of the General and Russian Linguistics Department, Philological Faculty, Peoples' Friendship University of Russia - RUDN University. Research interests: theory of language, linguistic semantics and pragmatics, language and speech stylistics; email: 1042198008@rudn.ru 